\title{
INFLUENCE OF FOOTINGS RIGIDITY AND SUBSOIL ON PUNCHING RESISTANCE
}

\author{
L. Fillo*, K. Laco**, T. Augustín ${ }^{* * *}$
}

\begin{abstract}
The presented paper will bring new aspects of punching resistance verification of concrete column footings coming from influence of ground stresses distribution depended on footing rigidity and a type of subsoil. The punching verification of flat footings comes from design criteria which depend on the punching resistance defined from crushing of concrete struts or from shear-bending failure with or without shear reinforcement.
\end{abstract}

\section{Keywords: footings, punching, shear resistance, rigidity, subsoil}

\section{Introduction}

There are two possible ways of structural failure due to punching. The first one is a strut diagonal failure (crushing of concrete) at control perimeter $u_{0}$ of a column. The second one is the shear-tension failure of concrete or transverse reinforcement in circumference of the area surrounded by control perimeters $u_{\mathrm{i}}$, which are analysed in distances from $0.5 d$ until $2.0 d$ from face of the column (Fig. 1).
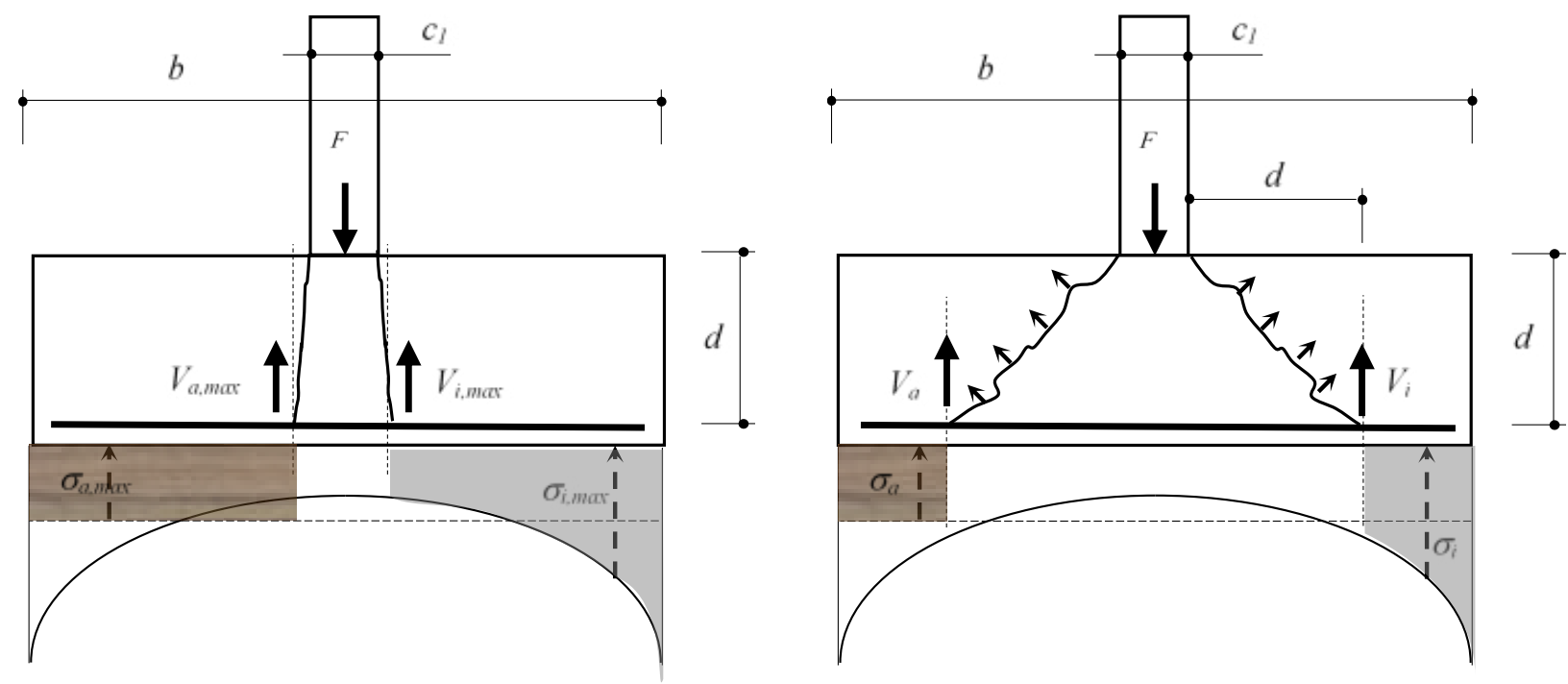

Fig.1: Failure of concrete footing; crushing of concrete and shear-tension failure

\footnotetext{
Prof. Ing. Ludovít Fillo, PhD.: Faculty of Civil Engineering STU in Bratislava, Radlinského 11; 810 05, Bratislava; SK, ludovit.fillo@stuba.sk

** Ing. Kamil Laco: Faculty of Civil Engineering STU in Bratislava, Radlinského 11; 810 05, Bratislava; SK, kamil.laco@stuba.sk

*** Ing. Tomáš Augustín: Faculty of Civil Engineering STU in Bratislava, Radlinského 11; 810 05, Bratislava; SK, tomas.augustin@stuba.sk
} 


\section{Verification of punching}

The maximum shear force is limited by the compressive capacity of the struts at the column perimeter. Crushing of the struts at column perimeter is controlled by the reduced compressive strength of concrete (1) according to EN 1992-1-1(2004).

$$
\begin{gathered}
v_{E d \max }=\frac{\beta V_{E d}}{u_{0} d} \leq v_{R d \max }=0,5^{*} v f_{c d} \\
v=0,6\left(1-\frac{f_{c k}}{250}\right)
\end{gathered}
$$

$* 0,5$ by precise calculation of $\beta$ or by $\beta=1$; otherwise 0,4 (Ruiz et al., 2014).

Limits for the punching resistance are derived from concrete shear-tension resistance without shear reinforcement (3) and shear-tension resistance with shear reinforcement (4). The maximum punching shear resistance is based on the $k_{\max }$ factor.

$$
\begin{gathered}
v_{R d c}=\frac{0,18}{\gamma_{c}} k\left(100 \rho_{l} f_{c k}\right)^{1 / 3} \frac{2 d}{a} \geq 0,035 k^{3 / 2} f_{c k}^{1 / 2} \frac{2 d}{a} \\
v_{R d c s}=0,75 v_{R d c}+\frac{1,5 d}{s_{r}} \frac{A_{s w} f_{y w d}}{u_{1} d} \leq k_{\max } v_{R d c}
\end{gathered}
$$

Verification by conditions of reliability needs more precise calculation of a punching shear force designing value $V_{i}$ or $V_{i, \max }$. These values are influenced by ground resistance distribution $\sigma_{\mathrm{i}}$ or $\sigma_{\mathrm{I}, \max }$ (Fig. 1). If we take into account uniform distributed ground stresses $\sigma_{\mathrm{a}}$ or $\sigma_{\mathrm{a}, \max }$, the $V_{\mathrm{a}}$ and $V_{\mathrm{a}, \max }$ - shear punching force values are less than $V_{i}$ or $V_{i, \max }$ - the more realistic shear punching force values and therefore the design of footings is on the unsafe side for both failure modes.
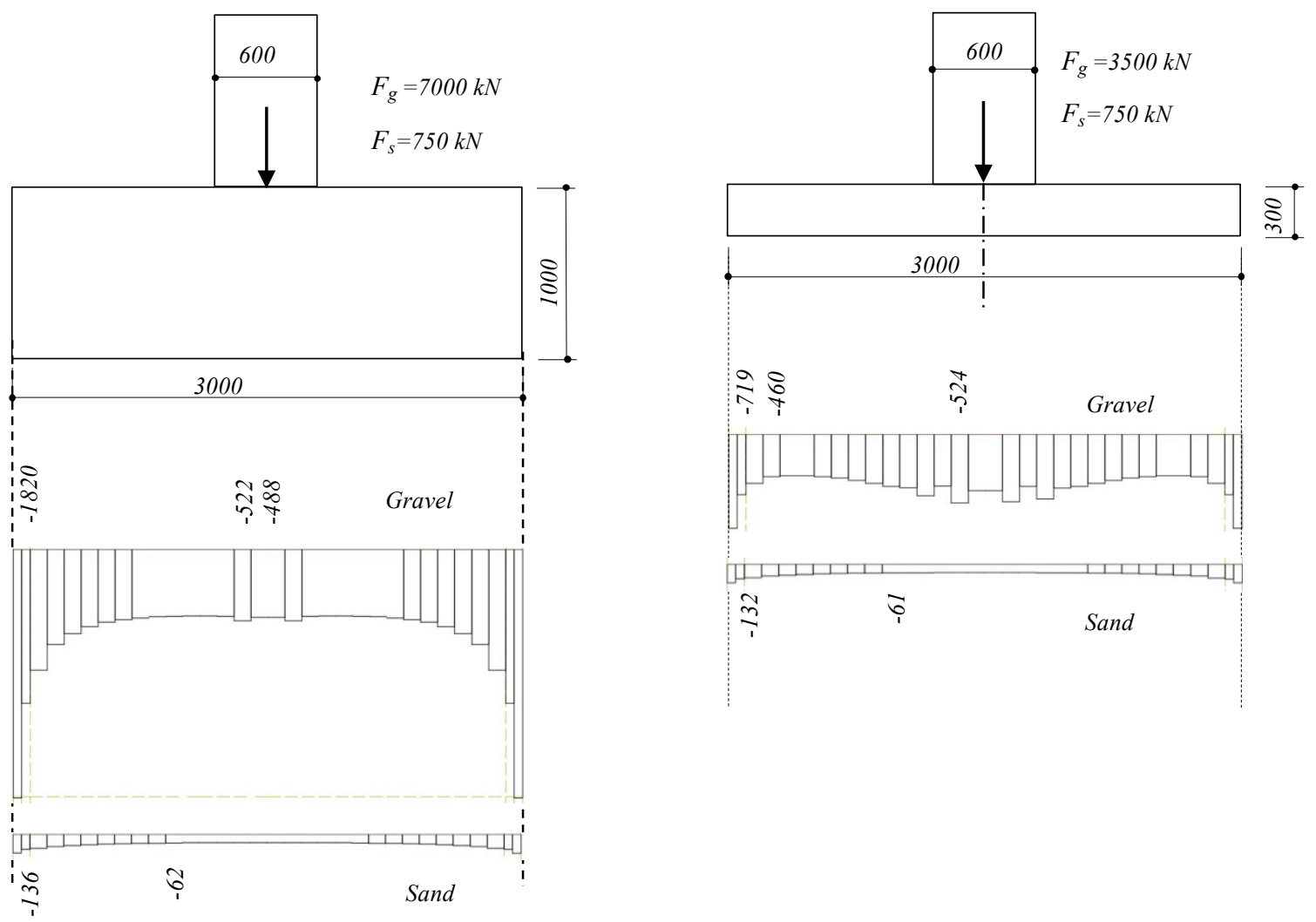

Fig.2: Ground stresses for two types of footings and subsoil 
Table 1: Comparison of simplified and more precise calculation of punching shear forces

\begin{tabular}{llllllll}
\hline Footing & Soil & $\mathrm{N}(\mathrm{kN})$ & $\mathrm{V}_{\mathrm{a}, \max }(\mathrm{kN})$ & $\mathrm{V}_{\mathrm{i}}(\mathrm{kN})$ & $\sigma_{\mathrm{a}}(\mathrm{kPa})$ & $\mathrm{V}_{\mathrm{a}}(\mathrm{kN})$ & $\mathrm{V}_{\mathrm{i}}(\mathrm{kN})$ \\
\hline rigid & gravel & 7000 & $\mathbf{6 6 7 0}$ & 6767 & 772 & $\mathbf{2 2 0 0}$ & 3581 \\
\hline rigid & sand & 750 & $\mathbf{7 0 0}$ & 711 & 81 & $\mathbf{2 3 1}$ & 303 \\
\hline flexible & gravel & 3500 & 3413 & 3364 & 395 & 3093 & 2989 \\
\hline flexible & sand & 750 & $\mathbf{7 0 0}$ & 708 & 81 & $\mathbf{6 3 4}$ & 657 \\
\hline
\end{tabular}

Distribution of ground stresses under footings was calculated by FEM analysis (see below) and compared with results of (Cajka et al., 2014) and (Labudková et al., 2016) and are shown on Fig. 2.

The goal of presenting analysis was to show that simplification in many cases does not lead to safe verification. These facts were confirmed by FEM analysis with rigid and partially also flexible footings and gravel and sand soil (Table 1). Max acting punching shear force for rigid footing and gravel soil calculated by average soil stress $\sigma_{\mathrm{z}}=772 \mathrm{kPa}$ was $\mathrm{V}_{\mathrm{a}, \max }=6670 \mathrm{kN}$. Calculated shear force from presenting analysis was $V_{I, \max }=6767 \mathrm{kN}$. Even bigger differences show punching shear force $\mathrm{V}_{\mathrm{a}}=2200 \mathrm{kN}$ versus $\mathrm{V}_{\mathrm{i}}=3581 \mathrm{kN}$ (Fig.1). Clearly are these results presented in Table 1.

\section{FEM analyses in SOFiSTIK}

A numerical model was created in FEM (Finite Element Method) based software SOFiSTiK. Both, soil and concrete elements were modelled as 3D brick elements with nonlinear material.

The geometry of the subsoil block has width and length of $17,4 \mathrm{~m}$ and $8,0 \mathrm{~m}$ height. Recommendation after (Jendželovský et al., 2014) and (Mistríková et al., 2012). The column footings had 2 types with varieties height. Width and length were $3,0 \mathrm{~m}$ and height was either $0,3 \mathrm{~m}$ or $1,0 \mathrm{~m}$. On top of the footing was also the column modelled for better transfer of the load to the footing. Width and length was $0,6 \mathrm{~m}$. On Fig. 3 the numerical model, for the $1,0 \mathrm{~m}$ height of the column footing, can be seen.

Nonlinear material of the concrete used in the analysis was Elasto-plastic material according to LADE with non-associated flow rule. The concrete parameters for the concrete material was set accordingly: $f_{c d}=20,0$ $\mathrm{MPa}, \mathrm{E}=32,0 \mathrm{MPa}, \mathrm{f}_{\mathrm{ctk} ; 0,05}=2,0 \mathrm{MPa}, \varepsilon_{\mathrm{tu}}$ (tensile failure strain) $=2,0 \%$.

For the subsoil was the Drucker-Prager soil model chosen. Two types should represent soft (sand) and rigid (gravel) foundation subsoil (Table 2). Type of the FEM calculation was non-linear analysis and additionally the effects of the geometrical system modification, e.g. length modification for big deformations. Numerical analysis used line search iteration method with an update of the tangent stiffness, if required.

Table 2: Types of foundation soil

\begin{tabular}{lll}
\hline Subsoil type: & Sand & Gravel \\
\hline \hline Nonlinear material & Drucker-Prager & Drucker-Prager \\
\hline Young's module $[\mathrm{MPa}]$ & 20,0 & 200,0 \\
\hline Poisson ratio & 0,25 & 0,40 \\
\hline Self-weight $\left[\mathrm{kN} / \mathrm{m}^{3}\right]$ & 19,0 & 23,0 \\
\hline Friction angle $\left[{ }^{\circ}\right]$ & 25,0 & 40,0 \\
\hline Cohesion $[\mathrm{kPa}]$ & 2,0 & 0,0 \\
\hline Dilatancy angle $\left[{ }^{\circ}\right]$ & 5,0 & 20,0 \\
\hline
\end{tabular}




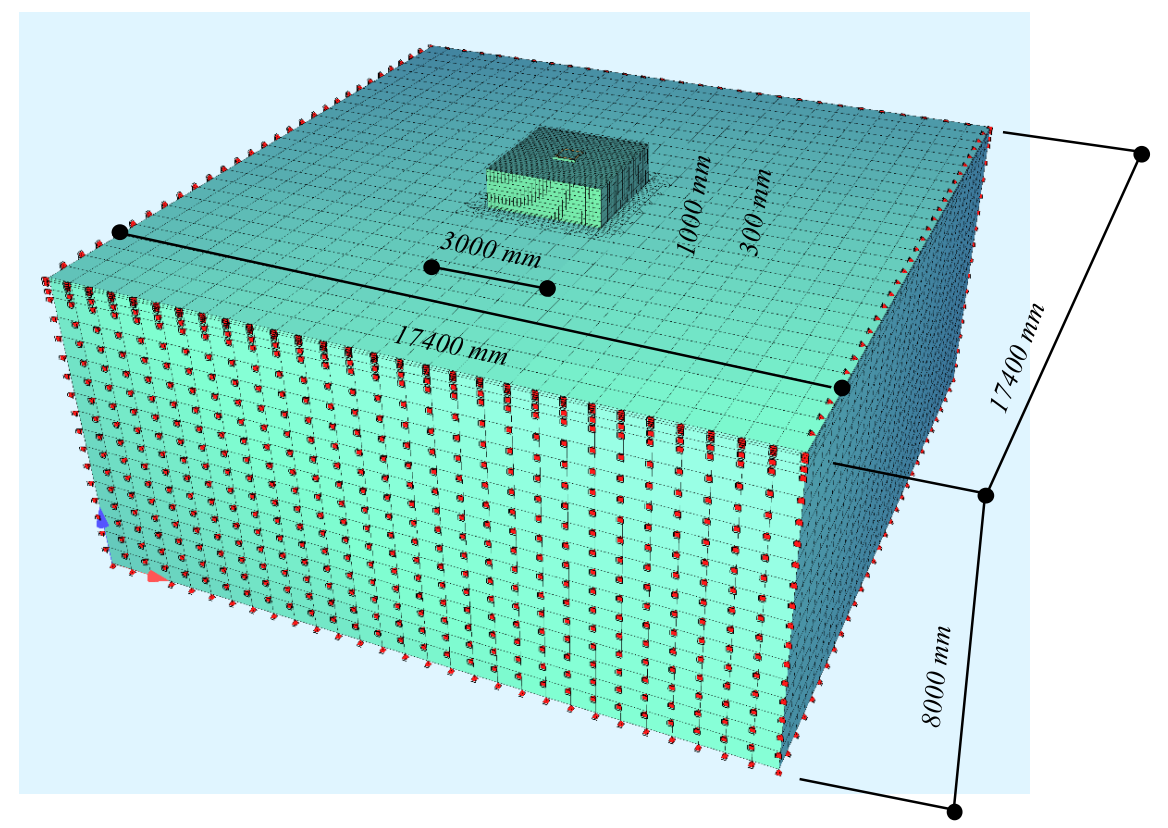

Fig.3: Geometry of the subsoil block

\section{Conclusions}

The presented paper brings new aspects of punching resistance verification of concrete column footings coming from influence of ground stress resistance distribution on punching verification. Results show that the verification of column footings - with the assumption of uniform - average - ground stresses distribution brings design on the unsafe side in 3 from 4 cases of footings and soil condition combinations (Table 1). The condition of reliability (1) and (3) could be satisfied only if we take into account the more precise analysis of soil stress distribution.

\section{Acknowledgement}

The authors gratefully acknowledge Scientific Grant Agency of the Ministry of Education of Slovak Republic and the Slovak Academy of Sciences VEGA č. 1/0810/16 and 1/0456/17.

\section{References}

Cajka, R. and Labudkova, J. (2014) Dependence of deformation of a plate on the subsoil in relation to the parameters of the 3D model. International Journal of Mechanics, Volume 8, Pages 208-215.

EN 1992-1-1(2004) Eurocode 2: Design of concrete structures - Part 1-1: General rules and rules for buildings.

Jendželovský, N. and Baláž, L. (2014) Modeling of a Gravel Base under the Cylindrical Tank. Advanced Materials Research, Vol. 969. pp.249-252.

Labudková, J. and Čajka, R.(2016) Numerical modeling of the interaction of subsoil and reinforced concrete slab. Solid State Phenomena. Volume 249 SSP, 2016, Pages 290-295.

Mistríková, Z. and Jendželovský, N. (2012) Static Analysis of the Cylindrical Tank Resting on Various Types of Subsoil. Journal of Civil Engineering and Management. Vol. 18, Issue 5 pp. 744-751.

Ruiz,M.F. and Muttoni, A. (2009) Application of Critical Shear Crack Theory to Punching of RC Slabs with Transverse Reinforcement. ACI Structural Journal V.106 No.4. 485-494 